\title{
A NEW TREMATASPID OSTEOSTRACAN, AESTIASPIS VIITAENSIS n.g., n. sp., FROM THE SILURIAN OF SAAREMAA, ESTONIA
}

\author{
Philippe JANVIER and Hervé LELIEVRE
}

U.R.A. 12 du C.N.R.S., Laboratoire de Paléontologie, Muséum National d'Histoire Naturelle (Paleontological Laboratory, National Museum of Natural History), 8, rue Buffon, 75005 Paris, France

Presented by D. Kaljo

Received December 29, 1993; accepted March 25, 1994

Abstract. A new tremataspid osteostracan, Aestiaspis viitaensis n.g., n.sp., is described from the Viita trench section in Saaremaa. It is characterized by an ornamentation of parallel, sinuous dentine ridges, and is the smallest known tremataspidid. Within the Thyestiida, it may be placed as a sister-group of all other Tremataspididae.

Key words: Osteostraci, Silurian, Estonia.

\section{INTRODUCTION}

Rich osteostracan faunas have been reported from the Silurian dolomites and limestones of Saaremaa since the mid-19th century (e. g., Eichwald, Pander, Schmidt, see references in Mяpcc, 1986, and Janvier, 1985), but they became better known in the 1930s, when the American zoologist and paleontologist W. Patten made extensive excavations in the Himmiste and Viita quarries, with the aim of discovering the "missing link" between the arthropods and vertebrates. The material collected by W. Patten is now deposited in the collection of the American Museum of Natural History (New York) and has been studied mainly by Robertson and Denison (see references in Janvier, 1985, or Mяpcc, 1986), and reviewed by Janvier (1985) in the frame of a phylogenetic analysis of the Thyestiida, and also by Afanassieva (Афанасьева, 1991).

Since World War II until the late 1980s, extensive excavations were difficult to make in Saaremaa, and the number of osteostracan species from these Estonian localities seemed to have reached its limit. During the field excursion of the 2nd International Colloquium on the Middle Palaeozoic Fishes (Tallinn, 1989), one of us (H. L.) collected a sample in the middle part of the Viita trench section in Saaremaa (see for details Kaljo \& Nestor, 1990, pp. 168-169). Later, during the processing of this sample with formic acid to extract vertebrate micro-remains, there appeared a small nearly complete shield of a hitherto unknown tremataspid osteostracan, whose dermal ornamentation differs radically from that of all other previously known tremataspids. This unique specimen, described herein, was prepared chemically on both sides and consolidated with cyanolit glue diluted in acetone. The preparation was affected with $10 \%$. formic acid neutralized with tricalcium phosphate. 
The specimen is slightly crushed dorsoventrally and part of its right side is damaged but it can be reconstructed by symmetry. Unfortunately, a few details in the orbitopineal region were damaged during preparation, but photographs and camera-lucida drawings made at each stage of the preparation have permitted to record some information.

The specimen is deposited in the collection of the Institute of Geology of the Estonian Academy of Sciences (TAGI) in Tallinn, with the registration number $\mathrm{Pi} 7279$.

\title{
PALEONTOLOGICAL STUDY
}

\author{
Class Osteostraci Lankester \\ Order Thyestiida Berg \\ Family Tremataspididae Woodward \\ Genus Aestiaspis n.g.
}

Diagnosis: same as for the type species.

Type species: Aestiaspis viitaensis n.sp.

Origin of name: from Aestii, ancient Latin name of the Estonian people.

\section{Aestiaspis viitaensis n.sp.}

(Figs. 1-6)

Diagnosis: A very small primitive Tremataspididae whose dermal ornament consists of slightly sinuous, longitudinal and parallel dentine ridges. The third and fourth external branchial openings are prolonged posteriorly by broad longitudinal grooves on the lateral flanges of the abdominal division.

Holotype: an almost complete head shield, TAGI Pi 7279 (Figs. 1-6).

Type level: Early Silurian, Late Wenlock, Rootsiküla Formation, Viita Beds.

Type locality: Viita trench, Saaremaa, Estonia; middle part of the section.

Origin of name: named after Viita, Saaremaa.

Remarks: A. viitaensis has the characteristic shield-shape of the Tremataspididae, with no area of attachment for paired fins, an elongated abdominal division, closely-set orbits, and endolymphatic ducts opening outside the median dorsal field. It can be regarded as quite generalized within the family, by its rather elongated lateral fields, lack of cosmine, and longitudinal rows of crest-shaped tubercles on the dorsal side of the abdominal division. It is the smallest known tremataspid and, among the Thyestiida, its size is comparable to that of Thyestes verrucosus Eichw.

Its type of ornamentation is very rare among the osteostracans and compares only with that of Ilemoraspis kirkinskayae Obr., from the Devonian of Khakassia (Afanassieva \& Janvier, 1985). However, it resembles also somewhat the tremataspid Timanaspiskossovoii Obr. (Koccoвой \& Обручев, 1962; Janvier, 1985). The five sharp dorsal ridges (ler 1 , 2, mdcr, Fig. 2) are probably a plesiomorphous characteristic for the Tremataspididae, since they occur also in their presumed sister-group, Thyestes verrucosus, as well as in the primitive tremataspids Timanaspis and Dartmuthia (Janvier, 1985). Some of the large tubercles of Thyestes verrucosus are also ornamented with very thin ridges which somewhat recall those of Aestiaspis (Афанасьева, 1991, P1. 6:3). 
Another unique feature of $A$. viitaensis is a deep longitudinal groove which prolongs posteriorly the fourth and fifth ex iernal branchial openings, along the flanges of the abdominal division (gr, Fig. 3).

Nothing indicates that the holotype of $A$. viitaensis could be a juvenile individual.

\section{DESCRIPTION}

The specimen Pi 7279 is almost complete, but dorsally flattened. It occurred in a thin layer of marl within a limestone block. The right anterior lateral part of the shield, the central part of the oralobranchial chamber and of the ventral covering of the abdominal division are poorly preserved (Figs. 1-3).

The abdominal and cephalic divisions, arbitrarily separated at the level of the external openings of the endolymphatic ducts, are nearly equal in length. There is no evidence of an area for the insertion of paired fins, and it is assumed that these were lost, as in other tremataspids (Stensiö, 1964; Janvier, 1985).

The ornamentation of the exoskeleton consists of thin dentinous ridges, arranged in parallel sinuous rows on the cephalic division, and more clearly longitudinal in orientation in the abdominal division (Figs. 2-5).

The dermal skeleton of the abdominal division clearly shows the limits between the scale-rows which are fused and incorporated to the head shield. In the rearmost part of this division, each incorporated scale-row may show indications of individual scales, in the form of their scalloped posterior edge, particularly on the ventral side. In this area, the individual scales of each row can be located by the presence of a somewhat larger ridge, flanked by ridges which decrease in breadth (Figs. 3,6 ).

On the dorsal side of the abdominal division, there are two longitudinal ridges (lcr 1, 2, Fig. 2) on each side of the median dorsal one (mdcr, Fig. 2). These ridges are made up of a series of prominent, drop-shaped crests on each scale-row. The lateralmost of these ridges (lcr2, Fig. 2) prolongs over the cephalic division, lining medially the lateral fields. The lateral margin of the cephalic division is prolonged posteriorly on the abdominal division by a sharp, serrated ridge (mcr, Fig. 2).

The median dorsal field (df, Fig. 2) is flanked on each side by a large, prominent tubercle (tb, Fig. 2), also ornamented with longitudinal ridges, with a larger one on top. Laterally to this large tubercle are two smaller tubercles.

On the margin of the cephalic division, the ridges of the ornamentation are parallel to the shield margin, and arranged in series (Fig. 2).

The flanges of the abdominal division are embayed by a deep longitudinal depression, which is divided into two grooves by a median ridge (gr, Fig. 3). The uppermost groove prolongs posteriorly the branchial notch of the third external branchial opening (bro3, Fig. 3), and the lower one that of the fourth branchial opening (see also Fig. $5 \mathrm{~B}$ ).

The ventral surface of the abdominal division is broad and flattened. The oralobranchial fenestra displays well-marked branchial notches, yet their total number is unknown, since the posterior margin of the fenestra is lacking.

The third to sixth branchial notches are separated by prominent knobs of dermal bone ornamented with sinuous ridges (ibrk, Fig. 3). The third notch is almost completely closed ventrally by a bridge of dermal bone. The supra-oral field bears a median series of pointed and backwardly pointing denticles, which decrease in size posteriorly (dt, Fig. 3). 


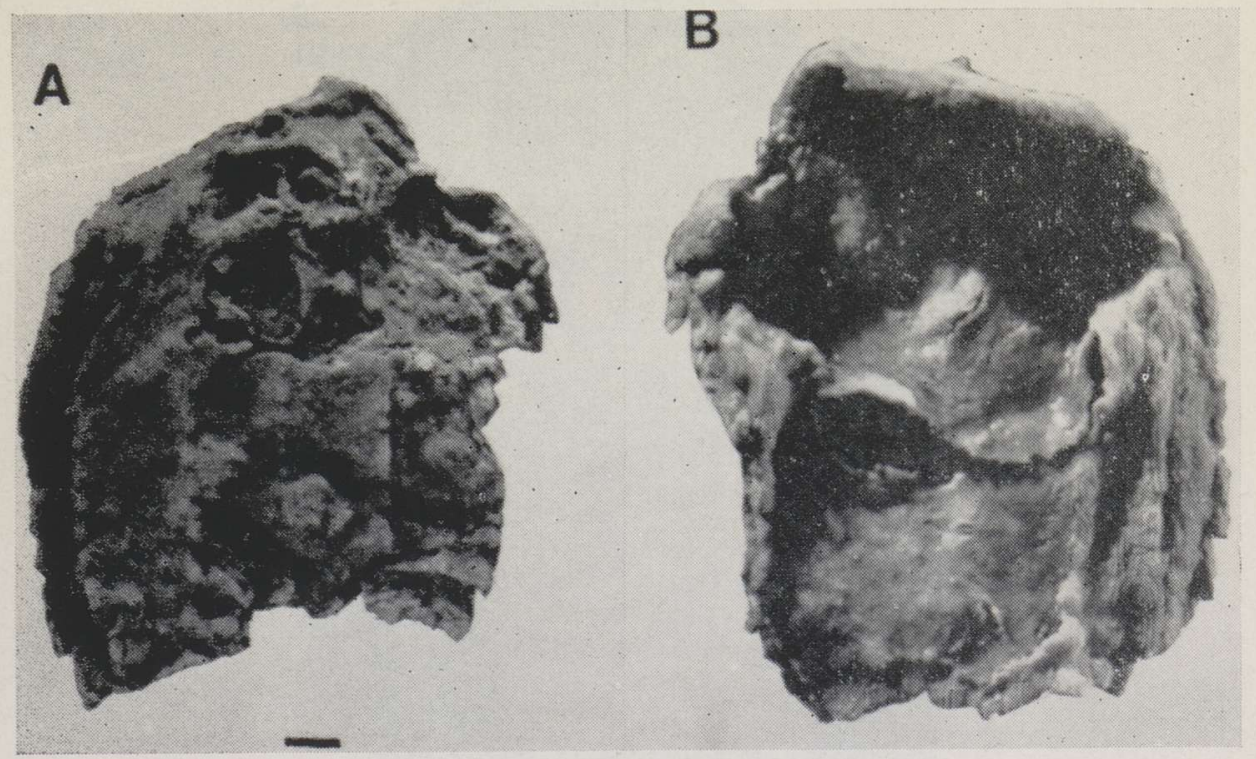

Fig. 1. Aestiaspis viitaensis n.g., n.sp., Early Silurian, Late Wenlockian, Viita trench, Saaremaa, Estonia. Holotype $(\mathrm{Pi} 7279)$ in dorsal $(A)$ and ventral $(B)$ view. Scale bar: $1 \mathrm{~mm}$.

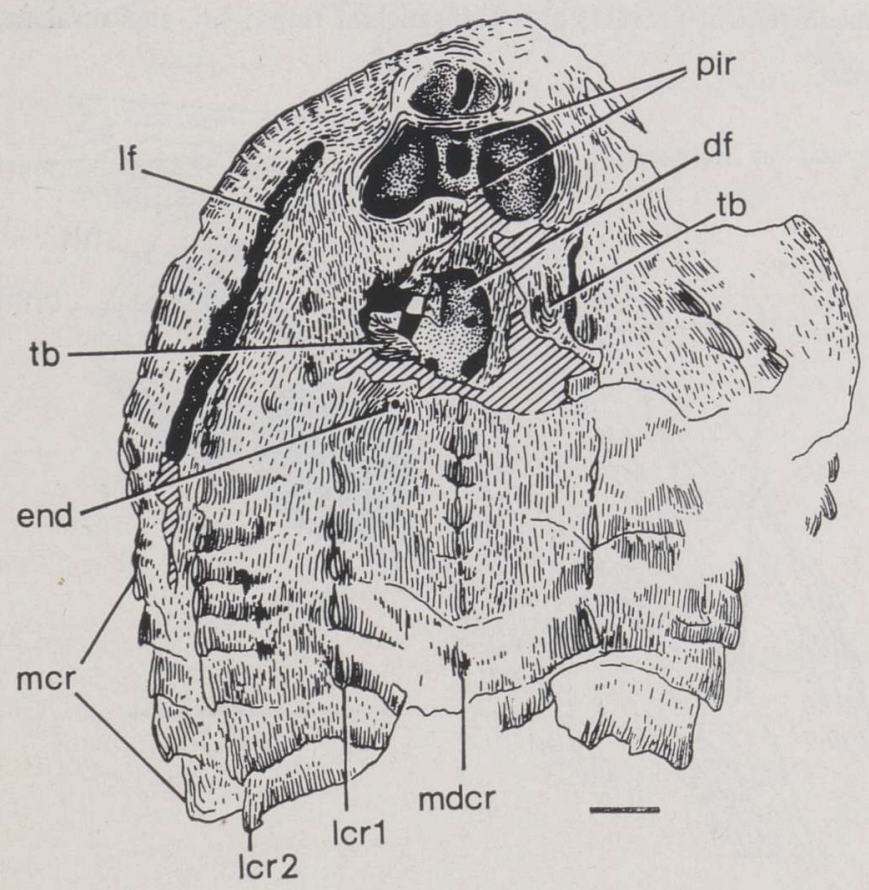

Fig. 2. Aestiaspis viitaensis n.g., n.sp., Early Silurian, Late Wenlockian, Viita trench, Saaremaa, Estonia. Camera-lucida drawing of the holotype (Pi 7279) in dorsal view. Scale bar: $1 \mathrm{~mm}$. df, median dorsal field; end, opening of endolymphatic duct; lcrl, 2, dorsolateral longitudinal ridges; lf, lateral field; mcr, marginal ridge; mdcr, median dorsal ridge; pir, pineal recess; tb, large tubercle, lateral to the median dorsal field. 


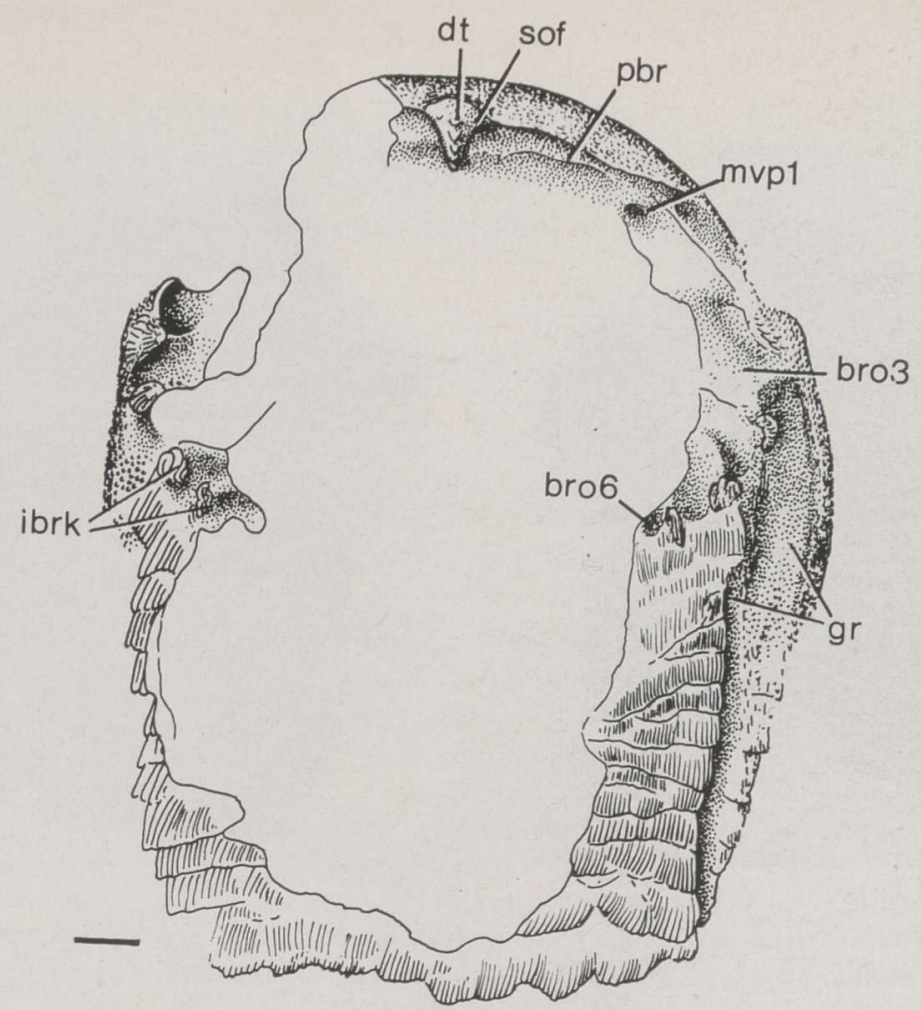

Fig. 3. Aestiaspis viitaensis n.g., n.sp., camera-lucida drawing of the holotype in ventral view. Scale bar: $1 \mathrm{~mm}$. bro3, 6 , notches for brancial opening; dt, denticles on supraoral field; gr, ventrolateral grooves; ibrk, interbranchial knobs of dermal bone; mvpl, first medioventral process; pbr, prebranchial ridge; sof, supraoral field.

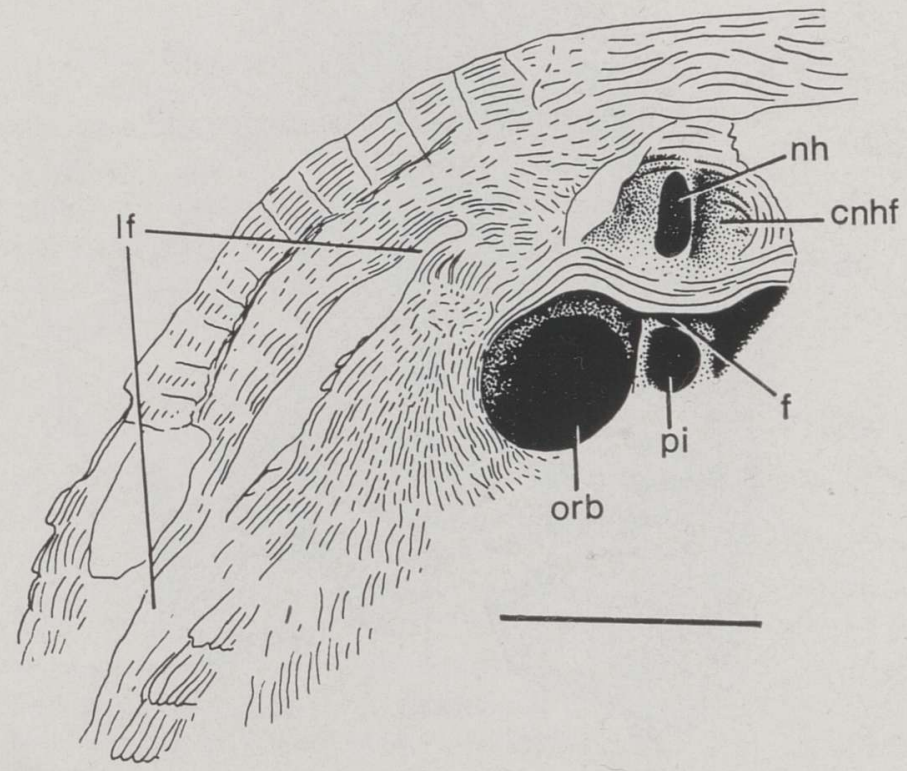

Fig. 4. Aestiaspis viitaensis n.g., n.sp., camera-lucida drawing of the orbitopineal and nasohypophysial regions of the holotype in dorsal view. Scale bar: $1 \mathrm{~mm}$. cnhf, circumnasohypophysial fossa; f, small foramen, possibly for the parapineal organ; lf, lateral field; nh, nasohypophysial opening; orb, orbit; pi, endopineal foramen. 

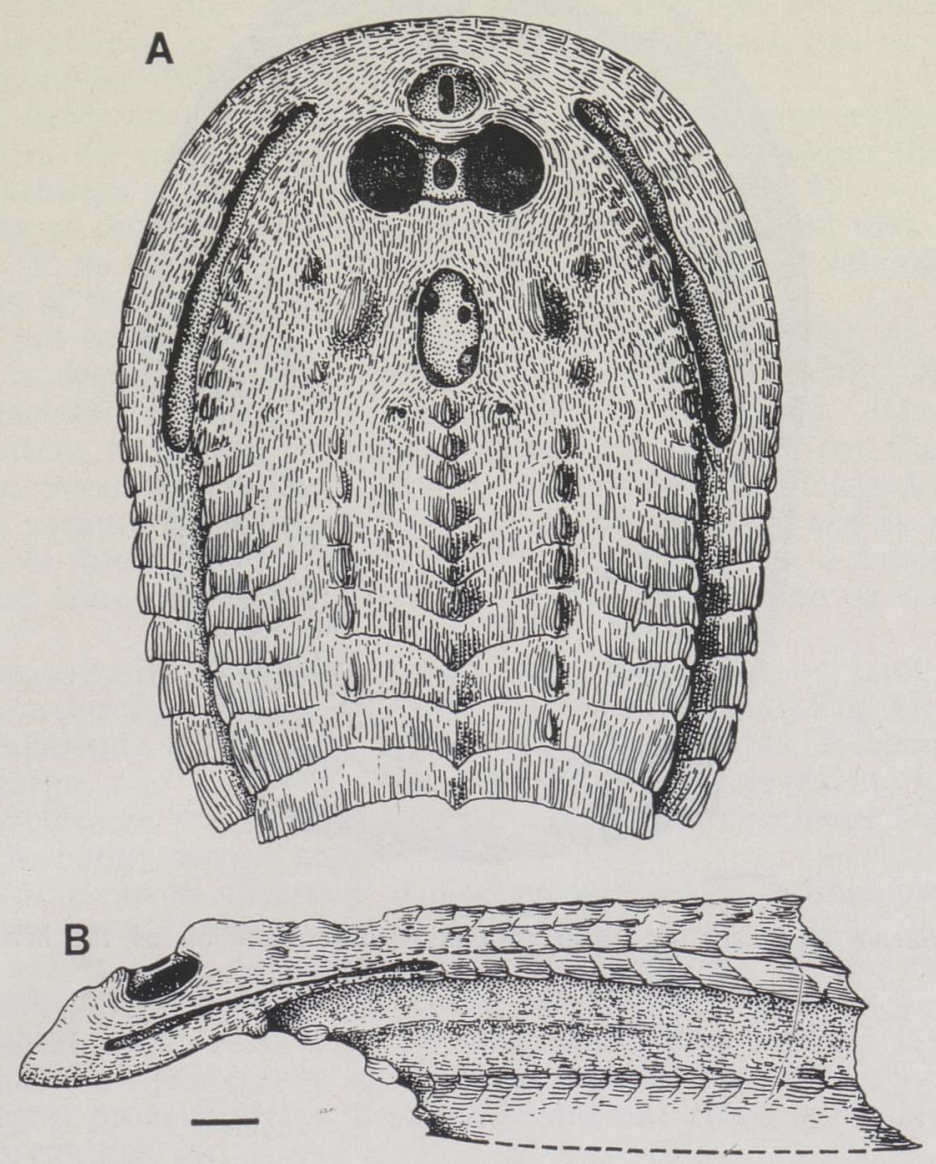

Fig. 5. Aestiaspis viitaensis n.g., n.sp., attempted reconstruction of the headshield in dorsal $(A)$ and lateral $(B)$ view. Scale bar: $1 \mathrm{~mm}$. 


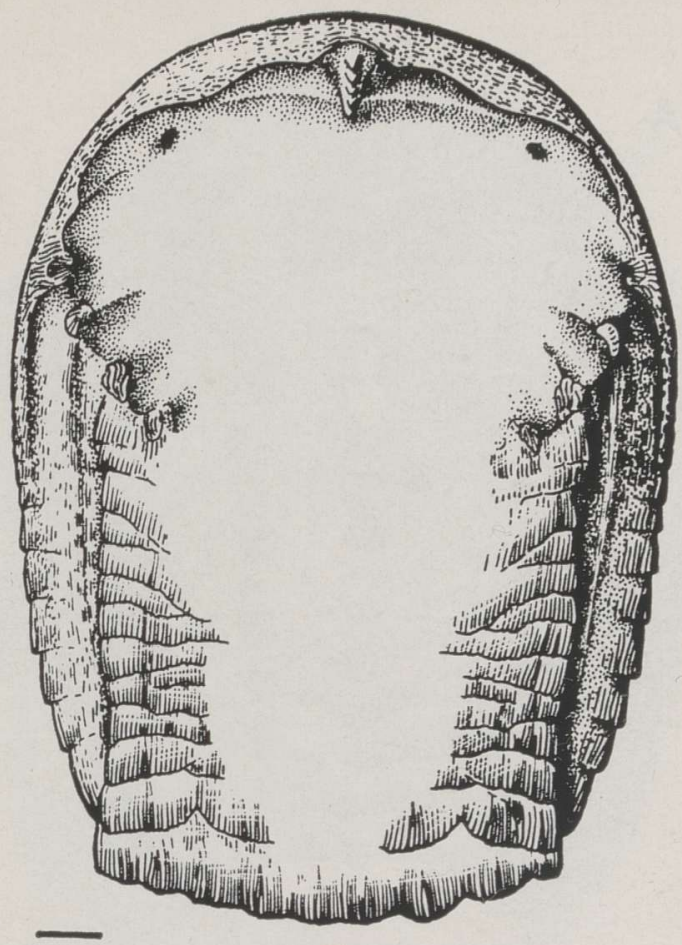

Fig. 6. Aestiaspis viitaensis n.g., n.sp., attempted reconstruction of the headshield in ventral view. Scale bar: $1 \mathrm{~mm}$. 
The median dorsal field (df. Fig. 2) is elliptic in shape, and its endoskeletal floor is pierced by large openings for the set canals, like in other tremataspids (Janvier, 1985, fig. 18).

The lateral fields are distorted but were elongated in shape, extending from the level of the nasohypophysial opening to slightly behind that of the external openings of the endolymphatic ducts (lf, Figs. 2, 4).

The opening of the endolymphatic duct is visible on the left side only (end, Fig. 2). It is rounded in shape, and situated well behind the posterior limits of the median dorsal field.

The orbits are comparatively large and closely set (orb, Fig. 4). The pineal recess is deep and narrow, and lined ventrally by perichondrally ossified endoskeleton (pir, Fig. 2). The latter, unfortunately damaged during preparation, is pierced by a large endopineal foramen (pi, Fig. 4) and a smaller, anteriorly placed foramen corresponding perhaps to the position of the parapineal organ (f, Fig. 4). Like in Thyestes, and to some extent Witaaspis, the pineal recess is limited posteriorly by a bilobated ridge of dermal bone, and anteriorly by a single median lobe of dermal bone (Fig. 5).

The nasohypophysial opening is slit-shaped and short, without any constriction between the nasal and hypophysial divisions (nh, Fig. 4), like in all other Thyestiida except Procephalaspis and Witaaspis. It opens in a relatively large and deep circumnasohypophysial depression (cnhf, Fig. 4). The surface of the latter is partly covered with dentinous ridges, and partly with spongy dermal bone.

No sensory line can be observed. It is assumed that these lines passed between the dentinous ridges of the ornamentation.

In ventral aspect, only the marginal part of the roof of the oralobranchial chamber is preserved. It shows well-marked grooves for the external branchial ducts (bro, Fig. 3), and small prebranchial fossae, which are bounded off posteriorly by the prebranchial ridge (pbr, Fig. 3). The medio-ventral process of the first interbranchial ridge is visible on the left side (mvpl, Fig. 3).

\section{PHYLOGENETIC AND SYSTEMATIC POSITION}

A cladistic analysis of 20 characters and 11 taxa (see matrix in Fig. 7A), including Aestiaspis, has been made, using the program PAUP. The two outgroups are a generalized osteostracan, Ateleaspis, and a rather generalized zenaspid cornuate, Scolenaspis. All other taxa (in group) are thyestiids (Procephalaspis, Witaaspis, Thyestes, Aestiaspis, Timanaspis, Dartmuthia, Saaremaaspis, Tremataspis, Oeselaspis). Five of the characters are multistate characters $(2,6,9,16,17)$ and $12.5 \%$ of the character codings are missing (coded as?). The characters are coded as follows (from left to right in Fig. $7 A$ ): 1, infraorbital sensory-line canal lateral $(0)$ or medial (1); 2 , canal for facial nerve passing through orbital cavity $(0)$, almost outside (1) or outside (2); 3 , medial recess of posteroventral myodome present $(0)$ or absent $(1) ; 4$, pineal plate broad $(0)$ or narrow (1); 5 , perforated horizontal lamina in sensory-line canals absent $(0)$ or present $(1) ; 6$, abdominal division of shield short $(0)$, moderately elongated (1) or very elongated (2); 7 , endolymphatic openings in median field $(0)$ or outside median field $(1) ; 8$, median field contacting pineal plate (0) or not (1); 9 , nasohypophysial opening long (0), short (1) or very short (2); 10 , nasal and hypophysial divisions of nasohypophysial opening well separated by a constriction $(0)$ or not separated (1); 11, enameloid in exoskeleton absent (0) or present (1); 
A

\begin{tabular}{|l|c|c|c|c|c|c|c|c|c|c|c|c|c|c|c|c|c|c|c|c|}
\hline & 1 & 2 & 3 & 4 & 5 & 6 & 7 & 8 & 9 & 10 & 11 & 12 & 13 & 14 & 15 & 16 & 17 & 10 & 19 & 20 \\
\hline Ateleaspis & 0 & $?$ & $?$ & 0 & 0 & 0 & 0 & 0 & 0 & 0 & $?$ & 0 & 0 & 0 & 0 & 0 & 0 & 0 & 0 & 0 \\
\hline Scolenaspis & 0 & 0 & 0 & 0 & 0 & 0 & 0 & 0 & 0 & 0 & 0 & 0 & 0 & 0 & 0 & 0 & 0 & 0 & 0 & 1 \\
\hline Procophalaspis & 1 & 1 & 1 & 0 & $?$ & 0 & 0 & 0 & 0 & 0 & 0 & 0 & 0 & 0 & 0 & 0 & 0 & 0 & 0 & 0 \\
\hline Witaaspis & 1 & $?$ & $?$ & 1 & $?$ & 1 & 1 & 1 & 0 & 0 & 1 & $?$ & $?$ & 0 & 0 & 1 & 1 & 0 & 0 & 0 \\
\hline Thyestes & 1 & 1 & 1 & 1 & 1 & 1 & 1 & 1 & 2 & 1 & 1 & 1 & 1 & 0 & 1 & 0 & 1 & 0 & 1 & 0 \\
\hline Aestiaspis & $?$ & $?$ & $?$ & 1 & $?$ & 1 & 1 & 1 & 1 & 1 & $?$ & 1 & 1 & 1 & 1 & 0 & 2 & 0 & 1 & 1 \\
\hline Timanaspis & $?$ & $?$ & $?$ & 0 & $?$ & 2 & 1 & 0 & 1 & 1 & $?$ & 1 & $?$ & 1 & 1 & 0 & 0 & 0 & 0 & 0 \\
\hline Dartmuthia & 1 & $?$ & $?$ & 0 & 1 & 2 & 1 & 1 & 1 & 1 & 1 & 1 & 1 & 1 & 1 & 1 & 1 & 0 & 0 & 1 \\
\hline Saaremaaspis & 1 & $?$ & $?$ & 1 & 1 & 2 & 1 & 1 & 2 & 0 & 1 & 0 & $?$ & 1 & 1 & 1 & 2 & 0 & 1 & 1 \\
\hline Tremataspis & 1 & 2 & 1 & 1 & 1 & 2 & 1 & 1 & 2 & 1 & 1 & 1 & 1 & 1 & 1 & 2 & 2 & 1 & 1 & 1 \\
\hline Desélaspis & 1 & 1 & 1 & 1 & 1 & 2 & 1 & 1 & 1 & 1 & 1 & 0 & 0 & 1 & 1 & 0 & 2 & 1 & 1 & 1 \\
\hline
\end{tabular}

B
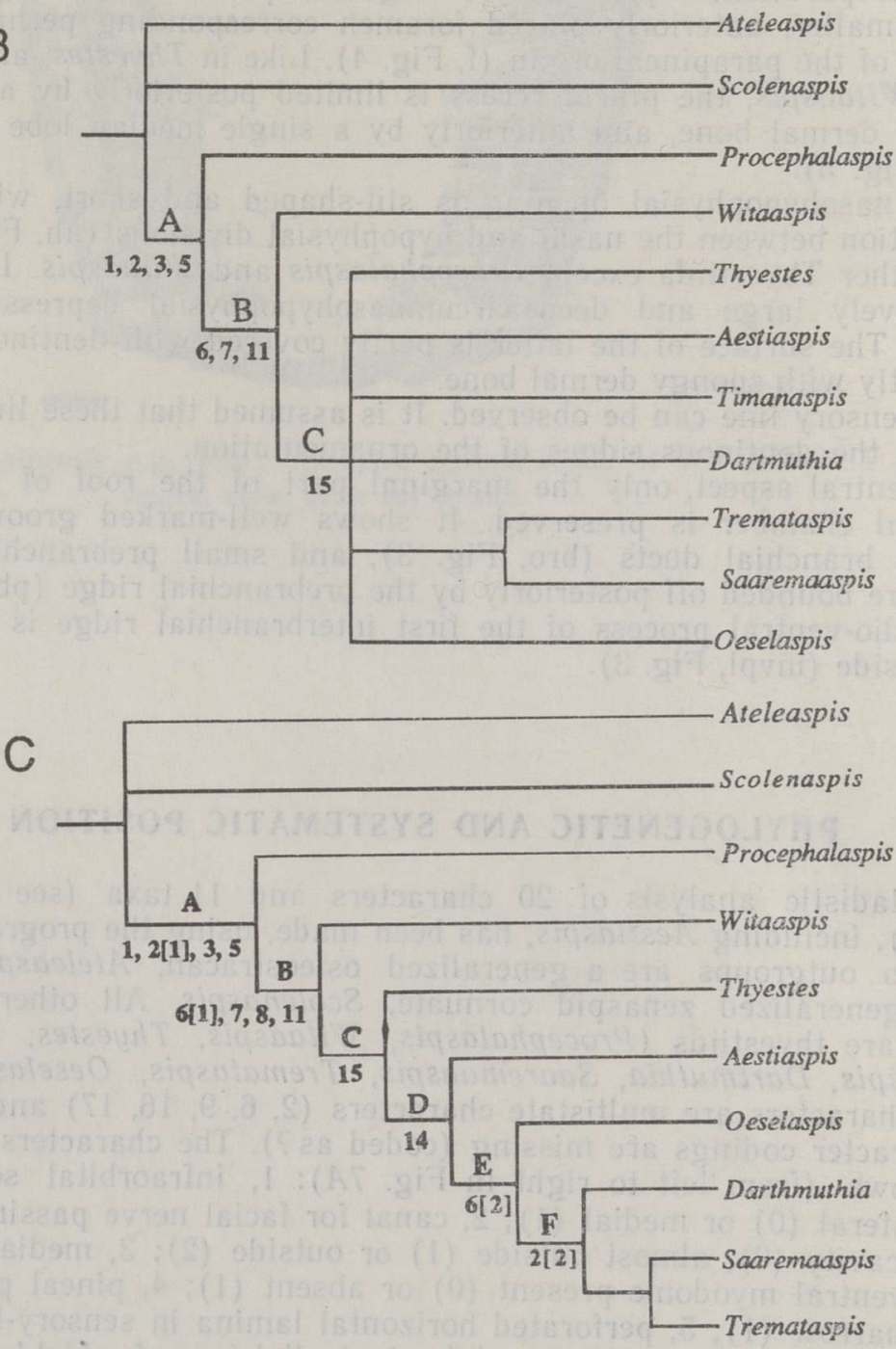

Fig. 7. Phylogenetic position of Aestiaspis viitaensis n.g., n.sp. among the Thyestiida. $A$, data matrix (outgroups generalized Ateleaspis and Scolenaspis, see text for characters and coding); $B$, strict consensus tree of the 10 most parsimonious trees; $C$, most parsimonious tree obtained when Timanaspis is deleted. Synapomorphies are indicated at nodes. In $C$. the state is indicated in brackets for multistate characters. For other characters, the apomorphous state is always [1]. 
12 , series of large tubercles on abdominal division absent $(0)$ or present (1); 13 , supraoral field without $(0)$ or with (1) denticles; 14 , paired fins present (0) or absent (1); 15, circumnasohypophysial depression triangular (0) or oval (1) in shape; 16 , cosmine absent $(0)$, present in part of the shield (1) or over all the shield (2); 17 , median field long (0), short (1) or very short (2); 18 , lateral fields undivided (0) or divided (1); 19 , prehypophysial region of shield long $(0)$ or short $(1) ; 20$, posterior end of lateral fields does not extend $(0)$ or extends (1) beyond the level of endolymphatic openings.

A first run was made using branch-and-bound search of the character matrix with all 11 taxa, and it yielded 10 equally parsimonious topologies at 40 evolutionary steps, with a consistency index $\mathrm{CI}=0.625$. In these topologies, the position of Timanaspis varies considerably, being the sister taxon of Dartmuthia in 7 topologies, and both forming a small clade which is the sister taxon of either [Saaremaaspis + Tremataspis], [Oeselaspis+ Aestiaspis + [Saaremaaspis + Tremataspis]], [Thyestes +Oeselaspis + Aestiaspis + [Saaremaaspis + Tremataspis]], or [Oeselaspis + [Saaremaaspis + Tremataspis]]. In the three other topologies, Timanaspis is a sister taxon of the remaining tremataspids (i.e. thyestiids minus Procephalaspis, Witaaspis, and Thyestes). The position of Procephalaspis and Thyestes is unambiguous. The strict consensus tree (Fig. $7 B$ ) of these ten trees shows three nodes (A, B, C) supported by eight uniquely derived characters among the congruent characters. Node A is supported by four unique shared derived characters (character state indicated in brackets) on characters 1[1], 2[1], 3[1], and 5[1]. Node B is supported by three unique shared derived characters $6[1], 7[1]$ and $11[1]$. Node $C$ is supported by one unique shared derived character 15[1].

Because of its ambiguous position, Timanaspis was deleted in a second run, which yielded a single most parsimonious tree (Fig. $7 C$ ), with a length of 36 evolutionary steps, or 36 total changes in the most parsimonious topology, and values of the consistency index $\mathrm{CI}=0.694$ and retention index $\mathrm{RI}=0.792$. Twelve unique shared derived characters among the congruent characters are retained to define six nodes ( $A$ to $F$ ). Node $A$ is diagnosed by four unique shared derived characters (no character transformation occurs at this node): $1[1], 2[1], 3[1], 5[1]$. Note B is supported by four unique shared derived characters: $6[1], 7[1], 8[1], 11[1]$; at this node three transformations occur, in characters 12[1], 13[1], and 17[1]; character $12[1->0]$ supports two reversals in Saaremaaspis and Oeselaspis. Node C is defined by one unique shared derived character, 15[1], and supported by three character transformations, 9[1], 10[1], and 19[1], with no reversal in the most parsimonious tree. Node D is supported by one unique shared derived character, 14[1]; at this node, two character transformations occur in 17[1] and 20[1], the latter occurring in parallel in one of the outgroups, Scolenaspis. Node $\mathrm{E}$ is supported by only one unique shared derived character, $6[2]$; this character is multistate and its state [1] supports node B. Node F is supported by one unique shared derived character, 2[2], which is also a multistate character and whose state [1] defined node A; one character transformation 16[1] also supports node $F$ but it occurs in parallel in Witaaspis. No synapomorphy supports the clade [Dartmuthia $+[$ Saaremaaspis + Tremataspis]], which is only defined by the transformation of character 9[2], which occurs, in parallel in Thyestes. 


\title{
REFERENCES
}

Afanassieva, O., Janvier, P. 1985. Tannuaspis, Tuvaspis and Ilemoraspis, endemic osteostracan genera from the Silurian and Devonian of Tuva and Khakassia (USSR). - Geobios, 18, 4, 493-505.

Janvier, P. 1985. Les Thyestidiens (Osteostraci) du Silurien de Saaremaa (Estonie). Ann. Paléont. (Verte.-Invert.). Première partie: Morphologie et anatomie, 71, 2, 83-147. Deuxième partie: Analyse phylogénétique, répartition stratigraphique, remarques sur les genres Auchenaspis, Timanaspis, Tyriaspis, Didymaspis, Sclerodus et Tannuaspis, $71,3,187-216$.

Kaljo, D., Nestor, H. (eds.). 1990. Field meeting, Estonia 1990. An Excursion Guidebook. Tallinn.

Stensiö, E. 1964. Les Cyclostomes fossiles ou Ostracodermes. - In: Piveteau, J. (ed.). Traité de Paléontologie, IV, 1. Masson, Paris, 96-382.

Афанасьева О. Б. 1991. Цефаласпиды Советского Союза (Agnatha). - Тр. Палеонтол. ин-та, 248.

Коссовой Л. С., Обручев Д. В. 1962. О нижнем девоне Северного Тимана. - Докл. AH CCCP, 147, 5, 1147-1150.

Мярсс Т. 1986. Позвоночные силура Эстонии и Западной Латвии. Валгус, Таллинн.

\section{UUS TREMATASPIIDNE OSTEOSTRAAK AESTIASPIS VIITAENSIS n.g., n.sp. SAAREMAA SILURIST}

\author{
Philippe JANVIER, Hervé LELIEVRE
}

Artiklis on kirjeldatud uut tremataspiidi (Osteostraci, Agnatha) taksonit Aestiaspis viitaensis n.g., n.sp. Eesti silurist. Leid pärineb Saaremaalt Viita kaeviku läbilõike keskmisest osast. Uue osteostraagi kilbi välispinna ornament, mis koosneb paralleelsetest looklevatest dentiinivallidest, on väga iseloomulik. Kala on väikseim teadaolev tremataspiid. Seltsi Thyestiida piires võib perekonda Aestiaspis vaadelda kui kõigi ülejäänud tremataspidiidide sõsargruppi.

\section{НОВЫЙ ТРЕМАТАСПИДНЫЙ ОСТЕОСТРАК AESTIASPIS VIITAENSIS n. g., n. sp. ИЗ СИЛУРА О-ВА СААРЕМАА, ЭСТОНИЯ}

\section{Филип ЖАНВЬЕ, Эрве ЛЕЛИЕВР}

Описан новый таксон трематаспид (Osteostraci, Agnatha) Aestiaspis viitaensis n.g., n. sp. из силура Эстонии, найденный в средней части окопного разреза в Вийта на о-ве Сааремаа. Новый представитель остеострак имеет своеобразный орнамент щита, который состоит из параллельных извилистых дентинных валиков. Из всех известных трематаспид эта рыба самая маленькая по размерам. Aestiaspis можно рассматривать как сестринскую группу всех остальных трематаспидид. 